\title{
Case report. Bacteriofagentherapie bij een cystoprostatitis
}

\author{
Charlotte J. van Ginkel (D) - Rob J. A. M. Davits
}

Published online: 5 June 2020

(C) The Author(s) 2020

Samenvatting Bacteriofagentherapie biedt mogelijk een oplossing voor de problemen van antibioticaresistentie. Ze werd toegepast in deze casus van een 71-jarige man met cystoprostatitis op basis van een multiresistente Klebsiella pneumoniae. De patiënt had sterk invaliderende klachten van nycturie en dysurie. Antibiotische behandeling hielp slechts tijdelijk. Behandeling met bacteriofagen, oraal en intravesicaal, resulteerde echter in afname van klachten, met tot nu toe blijvend succes. Het veilig gebruik met positieve resultaten van bacteriofagentherapie werd reeds beschreven in de (urologische) literatuur. De behandeling lijkt veelbelovend. Het opzetten van gerandomiseerde studies is nodig om te onderzoeken of deze therapie een oplossing kan zijn bij de problemen van de huidige toenemende antibioticaresistentie.

Trefwoorden bacteriofagen - cystoprostatitis • antibioticaresistentie

\section{Case report. Bacteriophages as therapy for cystoprostatitis}

\begin{abstract}
Bacteriophage therapy could be a solution for the rising problem of antibiotic resistance, as described in this case for cystoprostatitis. A 71-year-old man suffers from severe disabling nocturia and dysuria, because of a cystoprostatitis with a multiresistant Klebsiella pneumoniae. Whereas antibiotic treatment only gave temporary improvement, the treatment with bacteriophages, oral and intravesical, resulted in a decline of complaints so far. Positive results of treatment with bacteriophages are documented in

C. J. van Ginkel $(\bowtie)$ · R. J. A. M. Davits

afdeling Urologie, Elisabeth-TweeSteden Ziekenhuis,

Tilburg, Nederland

charlottevanginkel@hotmail.com
\end{abstract}

literature, as well as the safe use of them. Bacteriophage therapy seems promising. Randomized controlled trials are needed to research if this could be a solution for problems resolving from the increasing antibiotic resistance.

Keywords bacteriophages - cystoprostatitis . antibiotic resistance

\section{Introductie}

Antibioticaresistentie is in toenemende mate een mondiaal probleem [1]. Sinds de ontdekking van penicilline zijn antibiotica in vele varianten veelvuldig met succes toegepast bij infectieziekten. Momenteel is echter de werkzaamheid tegen diverse multiresistente bacteriën vaak niet meer afdoende [1]. Gezocht wordt naar oplossingen voor deze antibioticaresistentie en alternatieve behandelingen. Mogelijk kunnen bacteriofagen hierbij een rol spelen. Bacteriofagen, die ongeveer gelijktijdig met antibiotica werden ontdekt, zijn virussen die bacteriën kunnen doden (fig. 1). Ze zijn specifiek voor één type bacterie. Er zijn twee typen bacteriofagen. De lytische bacteriofaag injecteert zijn DNA-materiaal in de bacterie, die vervolgens het DNA multipliceert. Vervolgens barst de celwand open (=lysis) en komen de bacteriofaagdeeltjes vrij, waarna ze nieuwe bacteriën kunnen injecteren. Dit type bacteriofaag is bruikbaar voor therapeutische doeleinden, aangezien deze fagen de bacterie meteen doden. Het andere type bacteriofaag, van het lysogene type, nestelt zich in het DNA van de bacterie en kan lange tijd inactief blijven; dit type faag valt echter niet binnen de scoop van dit artikel. De specificiteit van de bacteriofaag heeft een aantal voordelen. Fagen zijn actief tegen multiresistente bacteriën. Vanwege de specificiteit tasten fagen het microbiële evenwicht niet aan. In de beperkte studies die op dit moment 


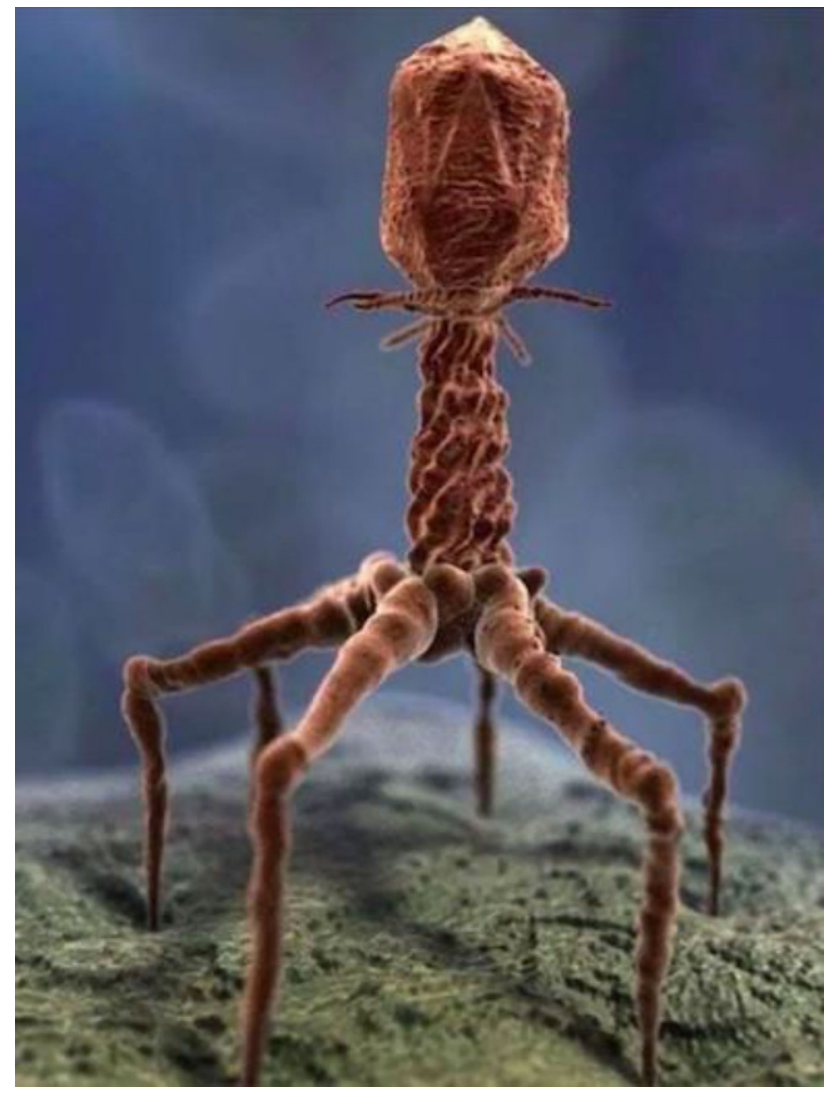

Figuur 1 Afbeelding van een bacteriofaag, gemaakt met een elektronenmicroscoop

beschikbaar zijn, werden geen bijwerkingen gemeld [2-6]. De specificiteit is echter tegelijkertijd ook een nadeel. Een passende faag vinden is een kostbaar en langdurig proces (enkele dagen). Zie fig. 2 voor een kant-en-klare fagenoplossing. De houdbaarheid en stabiliteit van een fagen(cocktail) is minimaal, een voorraad aanleggen is niet mogelijk [7]. Hierdoor hebben fagen geen plaats in de behandeling van acute bacteriële infecties [2]. Met name in Oost-Europa, onder andere in Tbilisi, Georgië, worden bacteriofagen al jaren toegepast. In 2018 is er een rapport uitgebracht door het RIVM waarin geconcludeerd wordt dat er te weinig gecontroleerd klinisch onderzoek is om bacteriofagen als antibacteriële behandeling te implementeren [2]. Het wetenschappelijk bewijs bestaat met name uit klinische ervaringen, enkele fase 1-onderzoeken en twee gerandomiseerde gecontroleerde studies [3-6].

\section{Casus}

Een 71-jarige man heeft nycturie, dysurie en koorts op basis van een persisterende cystoprostatitis met positieve urinekweken voor een multiresistente Klebsiella pneumoniae. In het verleden heeft hij eenmaal urineretentie gehad op basis van benigne prostaathyperplasie (40 cc, enige calcificaties), waarvoor medicamenteuze therapie volstond. Er zijn geen afwijkingen

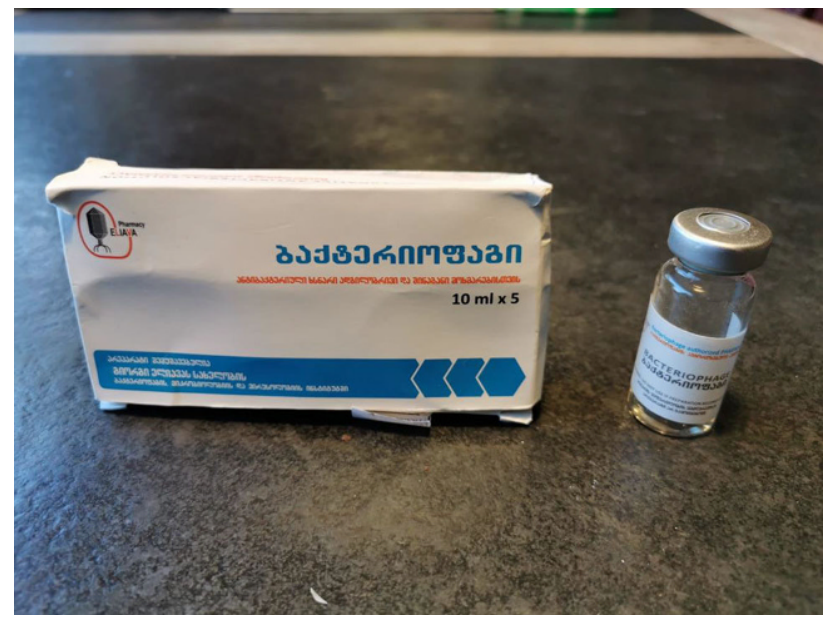

Figuur 2 Verpakking van een kant-en-klare fagenoplossing

aan de hogere urinewegen. De patiënt werd verwezen door de huisarts met het verzoek tot behandeling met intraveneuze antibiotica, omdat resultaat met antibiotica in de eerste lijn tot dan toe was uitgebleven, met onder meer nitrofurantoïne, fosfomycine, trimethoprim, cotrimoxazol en ciprofloxacine; exacte dosering en duur van de behandelingen zijn niet bekend. In het ziekenhuis werd de patiënt zeven dagen intraveneus behandeld met piperacilin/tazobactam $3 \mathrm{dd}$ $4.500 \mathrm{mg}$, op geleide van de urinekweek en in overleg met de medisch microbioloog. Later kreeg hij nog eens augmentin $3 \mathrm{dd} 625 \mathrm{mg}$ gedurende 10 dagen. Dit alles vond plaats in een tijdbestek van zeven maanden. De behandelingen hadden geen blijven effect op de klachten. Op een gegeven moment waren opioïden nodig om de pijn onder controle te krijgen. Bij toenemend invaliderende klachten en uitblijven van een succesvolle behandeling, zocht de patiënt op eigen initiatief hulp bij het Eliava Instituut in Tbilisi, Georgië.

Aldaar werd vervolgens een passende bacteriofaag voor zijn Klebsiella pneumoniae gezocht. Patiënt nam zelf de volle verantwoordelijkheid voor het effect en eventuele bijwerkingen van de behandeling in overleg met zijn behandeld artsen in Tbilisi. Naast de dagelijkse orale fagen, kreeg de patiënt acht wekelijkse intravesicale instillaties, die werden ingebracht via een CH14-eenmalige katheter, met $10 \mathrm{cc}$ fagen in $10 \mathrm{cc}$ fysiologisch zout, die hij gedurende 30-60 minuten in de blaas diende te houden. Na de vierde week ervaarde patiënt duidelijk een afname in nycturie en dysurie en na de vijfde week was zijn urinekweek negatief. Twee maanden na de laatste instillatie werd in de urinekweek toch weer een Klebsiella pneumoniae gevonden. Er werd expectatief gehandeld, omdat hij nauwelijks klinische klachten had. Later kreeg hij nog eenmaal antibiotica vanwege dysurie en nycturie, echter zonder effect. Opnieuw toedienen van de bacteriofagen zorgde voor een afname van de klachten, met tot nu toe blijvend succes. 


\title{
Hier staat een advertentie.
}

\author{
cC bohn \\ stafleu \\ van loghum
}

Houten 2020 


\title{
Hier staat een advertentie.
}

\author{
cC bohn \\ stafleu \\ van loghum
}

Houten 2020 


\section{Discussie}

In de casus werd de overstap gemaakt van antibiotica naar bacteriofagen. Binnen het spectrum van de antibiotische behandelingen waren echter nog andere mogelijkheden geweest. De behandelingsduur van een acute (cysto)prostatitis is 7-28 dagen; die van een chronische (cysto)prostatitis minimaal 28 dagen [8]. De behandelingsduur voor deze patiënt had uitgebreid kunnen worden. Bij de bacteriofagentherapie heeft de patiënt langdurig intravesicale blaasinstillaties gehad. In de richtlijn wordt ook gesproken over blaasinstillaties met antiseptische of antimicrobiële middelen [9]. Er kan dus niet met zekerheid gezegd worden dat de patiënt nooit op deze manier van zijn klachten verlost had kunnen worden. Op enig moment heeft hij echter zelf gekozen voor een poging met fagentherapie en dit ook zelf geïnitieerd.

De fagentherapie heeft in dit geval geleid tot vermindering van de klachten. De laatste jaren krijgt bacteriofagentherapie aandacht in de media als mogelijke oplossing bij de toenemende antibioticaresistentie. Fagentherapie is al eerder onder de aandacht geweest; in 1998 werd door Alisky et al. ook naar de rol van fagentherapie gekeken [10]. Een positief effect binnen de urologie werd beschreven door Alexandra Ujmajuridze et al. [11]. Zij voerden een prospectieve tweefasenstudie uit als pilot voor een gerandomiseerde gecontroleerde studie [11]. In deze studie werden 118 patiënten geïncludeerd met positieve urinekweken voor bepaalde uropathogenen. In vitro lieten de bacteriofagen na adaptaties een sensitiviteit van $75 \%(88 / 118)$ zien voor de betreffende uropathogenen. In vivo werden negen patiënten behandeld, van wie er zes $(65 \%)$ een daling van de bacterietiter lieten zien.

Uit de literatuur zijn twee randomised controlled trials (RCT's) bekend. Wright et al. onderzochten in hun RCT het gebruik van bacteriofagen bij chronische otitis op basis van antibioticaresistente Pseudomonas aeruginosa, waaruit zij concludeerden dat er bij hun patiënten significante klinische verbetering optrad en een significante verlaging van de bacterietiter [6]. In 2018 voerden Shafiqul et al. een gerandomiseerde gecontroleerde studie uit naar het gebruik van orale fagen, specifiek voor Escherichia coli, als therapie bij acute bacteriële diarree bij kinderen. Uit die studie bleek dat orale giften van fagen veilig zijn, maar klinische verbetering werd niet gevonden [5]. Het veilig gebruik van fagentherapie wordt door alle drie de studies onderstreept, zo ook in deze casus.

Verder wordt zelfs gespeculeerd over een combinatietherapie van antibiotica en bacteriofagen. In een review van Kutateladze en Adamia wordt de effectiviteit onderzocht van combinatietherapie bij de behandeling van een infectie met de Staphylococcus aureus [12]. In dit onderzoek verbeterde $78 \%$ van de patiënten in de combinatiegroep in vergelijking met $23 \%$ in de controlegroep die monotherapie met antibiotica kregen.

De werkzaamheid en bijwerkingen van fagentherapie zijn onvoldoende beschreven. Naast het mogelijke adaptatievermogen van de bacterie tegen de bacteriofaag, maakt men zich ook zorgen over een ontstekingsreactie die mogelijk op dode bacteriën ontstaat in zo'n kort tijdsbestek. Hier is echter te weinig over opgeschreven om uitspraken over te doen $[2,7]$.

\section{Conclusie}

Deze casus laat zien dat behandeling van een cystoprostatitis met een resistente bacterie soms zeer moeilijk kan zijn. Als antibioticabehandeling faalt, kan behandeling met bacteriofagen mogelijk wel helpen. Zoals ook in de bestaande literatuur wordt beschreven, is het nodig om met behulp van gerandomiseerde gecontroleerde studies te onderzoeken of deze veelbelovende behandeling een rol kan spelen bij de problemen van toenemende antibioticaresistentie.

Open Access This article is distributed under the terms of the Creative Commons Attribution 4.0 International License (http://creativecommons.org/licenses/by/4.0/), which permits unrestricted use, distribution, and reproduction in any medium, provided you give appropriate credit to the original author(s) and the source, provide a link to the Creative Commons license, and indicate if changes were made.

\section{Literatuur}

1. World Health Organization regional office for Europe. Central Asian and Eastern European surveillance of antimicrobial resistance. Annual report 2017. Geneve: WHO; 2017.

2. David S, Bijkerk P, Vlugt C van der, Beishuizen B. RIVM Briefrapport-bacteriofagen: huidige kennis, onderzoeken toepassingen. Bilthoven: RIVM;2018.

3. Schooley RT, Biswas B, Gill JJ, Hernandez-Morales A, Lancaster J, et al. Development and use of personalized bacteriophage-based therapeutic cocktails to treat a patient with a disseminated resistant Acinetobacter baumannii infection. Antimicrob Agents Chemother. 2017;61(10):e0095417.

4. Rhoads DD, Wolcott RD, Kuskowski MA, Wolcott BM, Ward LS, Sulakvelidze A. Bacteriophage therapy of venous legulcers in humans: results of a phaseI safety trial. JWound Care. 2009;18(6):237-43.

5. Sarker SA, Sultana S, Reuteler G, Moine D, Descombes P, Charton F, et al. Oral phage therapy of acute bacterial diarrhea with two coliphage preparations: a randomized trial in children from Bangladesh. EBioMedicine. 2016;4:124-37.

6. WrightA, Hawkins CH, AnggårdEE, Harper DR.A controlled clinical trial of a therapeutic bacteriophage preparation in chronic otitis due to antibiotic-resistant Pseudomonas aeruginosa; a preliminary report of efficacy. Clin Otolaryngol. 2009;34(4):349-57.

7. Cisek AA, Dabrowska I, Gregorczyk KP, Wyzewski Z. Phage therapy in bacterial infections treatment: one huderd years after the discovery of bacteriophages. Curr Microbiol. 2017;74(2):277-83.

8. Stichting Werkgroep Antibioticabeleid (SWAB). SWAB richtlijn antimicrobiële therapie bij gecompliceerde urine- 


\section{Case Report}

weginfectie. Amsterdam: Academisch Medisch Centrum, afdeling Infectieziekten, Tropische Geneeskunde en aids; 2006.

9. Nederlandse Vereniging voor Urologie (NVU). Conceptrichtlijn urineweginfecties bij volwassenen. 2020. https:// www.nvu.nl/en-us/kwaliteit/richtlijnen/ actuelerichtlijnen.aspx. Geraadpleegd op: 14 apr 2020.

10. Alisky J, Iczkowski K, Rapoport A, Troitsky N. Bacteriophages show promise as antimicrobial agents. J Infect. 1998;36(1):5-15.
11. Ujmajuridze A, Chanishvili N, Goderdzishvili M, Leitner L, Mehnert U, Chkhotua A, et al. Adapted bacteriophages for treating urinary tract infections. Front Microbiol. 2018;9:1832.

12. Kutateladze M, Adamia R. Bacteriophages as potential new therapeutics to replace or supplement antibiotics. Trends Biotechnol. 2010;28(12):591-5.

Charlotte J. van Ginkel, masterstudent geneeskunde Rob J.A.M. Davits, uroloog 